\author{
教 育 講 演 \\ 肺気腫・肺線維症 ${ }^{*}$ \\ 北海道大学医学部第一内科 \\ 村尾誠

\section{PULMONARY EMPHYSEMA AND FIBROSIS} \\ Makoto MUrao, MD \\ The First Department of Internal Medicine, Hokkaido University, School of Medicine, Sapporo
}

肺気腫は, 肺胞構造が壁の破壊を伴つて膨脹し た病像であり，換気に伴つて気道閉塞性障害を呈 する疾患である.一方, 肺線維症は, 肺胞構造が 壁の肥厚・硬化を伴つて縮小した病像であり，換 気に伴つて拘束性障害を呈する疾患である.禹疾 患はこのよらに相反する特徵を示すが，両者とも 肺損傷の最終像であり，全肺野にびまん性におこ り，患者は呼吸不全に陷り易く，之の予防・治療 が困難であるので, 呼吸器病学上大きな課題とな つている.

\section{肺気腫}

定義は病理解剖学的所見によつて，「終末細気 管支より末梢の呼吸領域が破壊を伴つて恒久的に 増大した状態である」とされている，それは，慢 性気管支炎，気管支喘息のあるものが臨末的には 肺気腫に極めて類似することがあるので，本症を 確実に鑑別するために病理形態像の特徽を強調し たものである. 従つて, その臨床診断に当つて は，1）肺内気量の増大した証拠，2）肺胞構造 の破壊・拡張があり不可逆性であることの証拠，

3）換気に伴う閉塞性障害の証拠，4）呼吸不全

*本講演は1977年 4 月 8日, 東京都千代田区霞ヶ関 久保講堂にて行なかれた。
の証拠，を明らかにすることが要請される，1），2） は, 樽状胸郭, 鼓性打診音, $\mathrm{X}$ 線像上の肺の過讋 脹ならびに紋理の末梢狭小化・哀失によつて推定 される，放射能物質の吸入扎よび静脈注入による 肺シンチグラムは, 肺内での換気・血流の不均等 性を明示する。肺胞・細気管支選択的造影法に上 れば局所の末梢細気道ならびに肺胞構造の破壊， 抎大像がある程度表現されうる，3)は，呼気相に 颃ける乎吸音延長・ラ音・呼吸困難としてとらえ られ, 迅速肺活量測定曲線上の特有の折れ曲り, 1 秒量の低下によつて示される。気管支払張剂 による閉塞症状の改善が認め難いのる特徽であ る.4)は，呼吸機能検査によつて数量的に示され る. 動脈血酸素分圧の低下が次第に高度となり， 炭酸ガス分圧は軽症時にはむしろ低く，やがて体 内蓄積をきたして高値を示すようになる，本症に 怙ける呼吸不全は, 肺胞毛細血管床の減少ならび に換気/血流比の肺内不均等性に主因があるすの と考えられており，その特徽は肺シンチグラムの 他, 動肺コンブライフンスの呼吸数依存性, 酸素 吸入後の呼出肺胞気窒素分析に打けるクリアラン スの遅延などにおいて著明である。

肺気腫の病像を注意して観察すると, 臨床的に 
も, 病理形態学的にも二つのタイプが識別され る, 臨床像における二つのタイプは, 肺気腫優位 型（A 型）と慢性気管支炎伾位型(B 型)，仇名で 呼べばpink puffers（赤あ方ぎ型）とblue bloaters （青ぶくれ型）である。前者は，老令に達して発 病し，やせており，せき・たんは少なく，体動時 の呼吸困難 は著明であるが，動脈血酸素分圧は 比較的高く保たれ，炭酸ガス蓄積も少なく，へマ トクリット上昇むなく, 心胸郭比は小さい。後者 は，比較的若年層からす発病し，やせは目立た ず，せきたんは比較的多く，体動時の呼吸困難 は比較的軽いが, 動脈血酸素分圧の低下, 炭酸ガ ス分王の上昇，へマトクリット増加傾向があり， 右心室肥大・拡張・不全汇宿りやすい。をより 両型には重なり合いがあり, 中間型 (X型)とし て取扱う場合もある。わたくしどすの経験では， 中間型はA，B型どちらかの病像が進展して他の型 の病像を加味したものが多く，一般により重症で ある。

病理形態学的には, 汎小葉型, 小葉中心型が区 別されている．前者は，肺胞覆まで細葉構造全体 が破罣・膨脹した型であり，後者は，呼吸細気管 支を中心とした部位の壁の破壊・膨脹した型であ る.両型は同一人の肺内でしばしば混在して観察 される.肺胞・細気管支選択的造影法の進歩によ つて，生前にもある程度まで両型が弁別できるよ らになつた。年代別病理解剖所見からみると， 前者は50才台より増加して拉り，後者は30〜40才 より漸増している(山中). 臨床像の 2 型と病理形 態像の 2 型との 対比研究 は興味深いるのである が，今日までの資料では，その対応は明らかでな w.

びまん性肺気腫に関連して, 老人肺と気腫性衰 胞の多発型とが問題となるであるう。老人肺は肺 胞導管の破壊を伴わない桩張像が特徵であり，臨 床的には肺気量の增加はあるが, 閉塞性障害はき たさないものと理解されている.気腫性襄胞は局 在性の場合には，X線像上紋理培失部位として注 目されるが，全般的肺機能面，臨床症状としての
障害は現われ難いものであるが，それが広範囲を 占め, 多発する場合には, びまん性閉塞性肺気腫 像に類似してくる。

気腫肺は, 形態学的に弾性線維の断裂が目立 ち，また実験的にもパパイン，エラスターゼの吸 入あるい梳酵素をもつ白血球・マクロファーシ の吸入によつて，ヒトの肺気腫に似た病像を作製 しらること等から, ェラスチンの変化が気隀肺の 生化学的変化の主点としては注目されている.乙 かし，今日までの検索成績では，気腫肺組織のエ ラスチン, コラゲン量の増隇は明確には証明され ていない，アミノ酸組成で非極性アミノ酸の減 少，基質物質としてのガラクトサミノグリカンの 比較的減少が指摘されているが，その意味づけは 将来に残されている， $\alpha_{1}$ アンチトリプシン欠損が 肺気腫と関連性をるつことが欧米諸国で注目され ている．日本に执いても，測定成績はあるが，㭱 とんどMM型であり，久損症自体の頻度もな特明 らかでない，肺気腫の成因仮設として，炎症・タ バュ・大気污染物質などの侵襲によつて肺胞腔で の細胞成分が増し，それらが破壊されるに伴って エラスターゼ活性をもつ酵素が放出され，エラス チンが犯される場で， $\alpha_{1}$ アンチトリプシン等でそ の活性を㧕制する機序を欠くと，気腫性変化が生 じ易くなると考劣る見方があり，それに応して重 視されているものである.

肺気腫患者の頻度は米国では過去20年にわたつ て漸增する傾向がみられて打り，1968年度人口10 万人対死亡率が 12 程度であつた。

日本での病理剖検輯報より抜きとり調查をした 数字では，肺気腫が主病変とみなされた者は人口 10 万人対死亡率に概算して 3 人程度であり，また 近年とくに増加したという傾向は認められない。 男は女より高率であり，契煙者には頻度が高いこ とがいくつかの統計資料から言われている。

本症の予後を不良にする因子としては，検査值 についてみると，1）肺性心による浮腫，2）心 電図での肺性 $\mathrm{P}$, 右室肥大像，3）1秒量の減少， 4）最大換気量の減少；5）動脈血酸素・炭酸ガ 
ス分王の異常，6）息切れ，7）拡散能力の低下, 8）安静時脈拍数の増加,なぞが挙げられ，それ ぞれの程度の著しい程, また重積因子が多いはど 予後が覀い傾向を示している.

予防治療にかんしては, 気道刺激物の排除, 感 染症合併の早期治療, 気道の浄化, 呼吸ならびに 循環系の管理強化, 呼吸訓練を含むりハビリテー ション等が挙げられる.

\section{肺線維症}

本症の定義は未だ一般的とは言えないが，「肺 胞壁に主座をもつ原因不明の間質性肺炎が進行性 で線維化を伴らもの」と限定して沶きたい．線維 化を扣こす肺疾患と言葉通りに広義に解釈する 之, 各種の原因既知・未知の肺疾患が挙げられる からである.すなわち，Hamman-Richのdiffuseinterstitial fibrosis of the lungs, Scadding $の$ cryptogenic fibrosing alveolitis, Liebowのusual type of interstitial pneumonia (unknow origin) の系 列に相当するものであり，厚生省特定疾患「肺線 維症」調查研究班が対象としたのもこの狭義の肺 線維症である.典型像の病理学的所見の特徽は， 肉眼的には, 胸膜の線維性瘾着はなく, 肺表面に は比較的均等な小結節状の凹凸が見られ，古い症 例では下葉の縮小・硬化がめだち, 線維化病変は びをん性で，とくに下葉に強く，病变は背側・底 部の胸膜下領域から始をつて批り，微小露胞の形 成を認めるものである、組織学的には, 肺胞壁の 肥厚, 硝子膜の形成があり，線維素，好中球の肺胞 内浸出および細気管支炎を欠き，呼吸細気管支を 中心とした小輁胞形成が認められるすのである. 臨床像としては，息ぎれ，頻呼吸，乾性せき，吸 気後半での高調性不連続性雑音, チアノービ, ば ら状指などが認められ，X線像では，背側・底部 上り始まりやがて全肺にひろがるびまん性のスり ガラス状, 粒状, 網状, 小輪状陰影が認められ, 肺は縮小・硬化の傾向をたどり，拘束性換気障 害，呼吸不全を和こするのである，吸気性ラ音は その類似性からvelcroラ音と呼ばれ，体位によ つて変化し，せき・たん喀出によつては変化しに
くい高調性不連続性特色から，特殊な共鳴音とし て理解される.呼吸機能検查では, 静肺コンプラ イアンスの低下, 肺活量の減少 (拘束性障害), 拡 散能力の低下（肺胞一毛細管ブロック症候群）が 認められ, 一方, 1 秒率, 気道抵抗值は正常で, 動肺コンプライアンスの呼吸数依存性は少ない のが特徵である。本症はalveolar-capillary block syndromeの代表疾患として有名であるが，桩散能 力の検查法は換気/血流の肺内分布不均等性に上 るガス交換異常の影響を除外できない点にかんし て，いく人かの反論があることを附言する．動脈 血酸素分圧は低下し，炭酸ガス分王は最終期に至 るまで低值を示す，血清LDH，GOTの上昇もし ばしば認められる。また、リンバ球の減少, $\gamma$-ク ロブリンの増加， RA反応抗肺抗体の陽性化など の免疫学的異常を推定させる所見を示す症例むあ る。

間質性肺炎の異型として，Liebowはusual type (UIP) のほかに，BIP(UIPに閉塞性細気管支炎 を伴う型)，LIP(リンパ球の浸潤が特異的である 型), GIP (巨細胞の出現が特異である型), DIP (肺胞垫内への剝離細胞の集積が著明である型) を挙げて拉り，それぞれ原因既知のもの未知のも のがありらることを述へ，またそれらが吸収され 治癒に向らものと，終局像として肺胞隔線維症に 至るものがありらることを述べている．厚生省班 研究ではUIP系列のみに限定して調查研究を行な つたが，米国での発表をみると狭義の肺線維症と 言つてもBIP系列のものをる加えているように思 われるので，資料を照合するとき留意すべきこと である。

線維化肺には組織学的にも肺胞壁の肥厚, 線維 成分の增加が認められ, 乾燥重量も増しているの で，当然ニラーゲンの増量があると思いがちであ るが, 意外にその点は明確でない，一つには，肺 のコラゲンは皮膚のそれにくらべて極めて難溶性 であるためでもある。しかし，努力して可溶性と することに成功した段階でもなおコラゲン量の増 加を明確に表示する指標が得がたい状態である。 
むしろ，コラゲンのタイプで $\alpha_{1}$ (I )， $\alpha_{1}$ (III) の比率が変つてくることを特徽として注目する傾 向がある．基質物質としては，デルマタン硫酸の 比較的増加が挙げられている(今野). 本症の発生 機序にかんする仮設としては，何等かの機転によ る組織破買が直接あるいは免疫学的機序を介して 肺胞壁の細胞反応を若起し，アクロファージは一 方では線維芽細胞遊走因子, 線維化促進因子を放 出し，他方では，コラゲナーゼを放出し，その均 衡の上でに融解治瘾に向らか, 線維化に向らかの 方向をたどる模型が考古れている。

本症の発症率, 有病率にかんしては次のよらな 調査成績がある．国有鉄道職員ならびに家族につ いての十年間の健康調查の成績から，本症が確認 される数は，每年 10 万人対 0.3 人の発病率である (近内). 新潟県下で行なわれた50才以上の住民の 健康調查の成續から，本症が確認された数は，10 万人対 3 人の有病率である(近藤). 結核実態調査 によるX線像陰影のみによる判定では，本症が疑 われる数は10万人対 23 人程度である(岩井).

全国症例調查にて集計した176例中家族発生が 5 家系証明されている. 男女比は1.5対 1 である が，30才台以下では女子に多い. 症例数のピーク は50〜60才台にある.病理剖検輯報により抜きと り調查してみると，本症による死亡率は僅かなが ら上昇の傾向があり，人口10万人対 1.5 人程度に概 算される。膠原病に伴 万肺線維症, 制癌剤等によ ると思われる線維化像を含めた死亡率の概算は10 万人対 15 人程度となつている，厚生省調査例の5 ち死亡例のみについてみると，発症より死亡まで の期間 6 カ月未満のものが $17.8 \%$ あ゙り，より長 い経過をたどる者が多い.15年以上の経過を示し た者す $10.2 \%$ ある.生存期間に関与したと思われ る因子を検査值について分析してみると，初診時 のLDHの高值, リンパ球数の低值, GOTの高值, pHの上昇, 動脈血酸素分仕の低值, 炭酸ガス分圧
の低值などが有意の相関因子として認められた。 本症の治療はな極めて困難である，最も多く 用いられるのはステロイドホルモン刘であり，そ の補助薬的な使用経験として免疫抑制剂，ラチ ローゲン剤が用いられている、ステロイドホルモ ンは，ある症例では100mg（プレドニソロン量と して）程度を用いて始めて有効の場合もあるが， 全国症例の使用経験のまとめから見ると，必ずし 大量療法が有効とも言えない上うである。一旦奏 効した後に滅量に伴つて再燃をきたす症例は少な くないし，また再然後の予後は一般に極めて悪い 傾向を示している。全般的に，粒状陰影など初期 像の時期炕用いたとき有効の症例が多いが，輪状 影を生じた進行型でも有効の症例があることも指 摘されている。

\section{文献}

(情性肺気䏸)

1) Murao M: Chronic Pulmonary Emphysema. Jap Circ J 19:1，1956. 一2) 中村隆 : 肺気嗹. 第 17回日本医学会総会学術俩演集, 4 巻 : 933 945, 1967. -3) Rodman T, Sterling FH: Pulmmonary emphysema and related lung diseases. Saint Louis Mosby 1，1969。－4）本間日臣，他：慢性閉塞性 肺疾患，東京。医学書院，1，1975. 一-5) Thurbeck WM: Chronic Airflow Obstruction in Lung Disease. Philablphia Saunders 1, 1976.

（肺線維症）

1) Hammar $L$ and Rich AR: Acute interstitial fibrosis of the lungs. Bull Johns Hopkins Hosp $74: 177,1944 .-2)$ Liebow AA: New Concepts of Entities in Pulmonary Disease in "The Lung" edited by Liebow AA, Smith DF Baltimore, Williams and Wilkins 332, 1968. -3) Petty TL and Filley GF (Chairmen): The 18th Aspen Lung Conference. Chest 69 (Suppl): 251, 1976. -4) Crystal RG (Moderator): Idiopathic Pulmonary Fibrosis (PIH Conference) Ann Int Med $85: 769$, 1976。－5）村尾誠（班長）：厚生省特定疾患「肺 楾程症」調查研究班, 昭和49年, 50年 (51年度) 研 究報告書, $1 \sim 132 ， 1975 ； 1 \sim 198 ， 1976$ (1977印 刷中)。 